\title{
A Framework for Assessing Food System Governance in Six Urban and Peri-Urban Regions in Sub-saharan Africa
}

\author{
Qiuzhen Chen ${ }^{1 *}$, Karlheinz Knickel ${ }^{1}$, Mehreteab Tesfai ${ }^{2}$, John Sumelius ${ }^{1}$, Alice Turinawe ${ }^{3}$, \\ Rosemary Emegu Isoto ${ }^{3}$ and Galyna Medyna ${ }^{4}$ \\ ${ }^{1}$ Department of Economics and Management, Faculty of Agriculture and Forestry, University of Helsinki., Helsinki, Finland, \\ ${ }^{2}$ Norwegian Institute of Bioeconomy Research, Division of Environment and Natural Resources, Department of Soil and Land \\ Use, Ås, Norway, ${ }^{3}$ Department of Agribusiness and Natural Resource Economics, School of Agricultural Sciences, Makerere \\ University, Kampala, Uganda, ${ }^{4}$ Natural Resources Institute Finland, Helsinki, Finland
}

\section{OPEN ACCESS}

Edited by:

Alessandro Galli,

Global Footprint Network

United States

Reviewed by:

Saba Siddiki,

Syracuse University, United States

Shuru Zhong,

Sun Yat-sen University, China

*Correspondence:

Qiuzhen Chen

chen.qiuzhen@helsinki.fi

Specialty section:

This article was submitted to Social Movements, Institutions and Governance,

a section of the journal

Frontiers in Sustainable Food Systems

Received: 23 August 2021

Accepted: 28 October 2021

Published: 30 November 2021

Citation:

Chen Q, Knickel K, Tesfai M, Sumelius J, Turinawe A, Isoto RE and Medyna G (2021) A Framework for Assessing Food System Governance in Six Urban and Peri-Urban Regions in Sub-saharan Africa.

Front. Sustain. Food Syst. 5:763352.

doi: 10.3389/fsufs. 2021.763352
An important goal across Sub-Saharan Africa (SSA), and globally, is to foster a healthy nutrition. A strengthening of the diversity, sustainability, resilience and connectivity of food systems is increasingly seen as a key leverage point. Governance arrangements play a central role in connecting sustainable, resilient farming with healthy nutrition. In this article, we elaborate a framework for assessing, monitoring and improving the governance of food systems. Our focus is on food chains in six peri-urban and urban regions in SSA. A literature review on food chain governance and a mapping of current agri-food chains in the six regions provide the basis for the elaboration of an indicator-based assessment framework. The framework is adapted to the specific conditions of SSA and related goals. The assessment framework is then used to identify the challenges and opportunities in food chain governance in the six regions. The first testing of the framework indicates that the approach can help to identify disconnects, conflicting goals and tensions in food systems, and to formulate strategies for empowering agri-food chain actors in transitioning toward more efficient, equitable and sustainable agri-food systems. The article is concluded with a brief reflection on the strengths and weaknesses of the framework and suggests further testing and refinement.

\section{Keywords: agri-food chain, assessment framework, indicators, food system, governance, Sub-Saharan Africa}

\section{INTRODUCTION}

Malnutrition in various forms, such as undernutrition, micronutrient deficiencies, overweight and obesity, exists in numerous countries, no matter whether they are low-, middle- or high-income (HLPE, 2017). Dietary patterns and trends vary significantly across world regions, currently worsening in some low-income countries in Africa, while middle-income countries are showing the largest improvement worldwide in diets and a healthier nutrition (Imamura et al., 2015). In many low-income countries, grain- or tuber-dominated diets tend to dominate as they are affordable for the rural, urban, and peri-urban poor, including smallholder farmer families. This in turn results in widespread undernutrition and specifically a lack of micronutrients (HLPE, 2017). It seems important to add here that Holmes et al. (2018) found that also diets dominated by processed food in Sub-Saharan Africa (SSA) that are particularly common in urban areas are problematic as they lead to overweight and obesity. 
Regarding an improved access to healthy, nutritious and diverse diets, it has been shown that home gardens, more diverse cropping systems and intercropping play a central role. Aquaculture and domestic animals are effective too in increasing diet diversity and improving nutritional status (Murshed and Pemsl, 2011; Carletto et al., 2015; Olney et al., 2015). The main constraint is the limited accessibility of more diverse food items for many consumers. HLPE (2017), in line with this, found that fresh fruits, vegetables and animal-based foods are often costly and inaccessible to the rural, urban, and peri-urban poor. They conclude that eating more traditional foods such as legumes, locally seasonal fruits, leafy vegetables and forest foods can significantly improve nutrition. Cernansky (2015) supports this view adding that African leafy vegetables have become important in East Africa in helping people to meet their dietary needs. The same author found that it tends to be women farmers who deliver leafy vegetables and other nutritious foods to markets.

The few examples are indicative of the importance of connecting producers, processors and consumers. HLPE (2017), in line with that, emphasizes that malnutrition will not be 'selfcorrected' by economic growth, that it needs to be addressed more directly by shaping food systems in a way that contributes to improved nutrition, and that food chain governance plays a central role in this.

In food systems, food chain governance arrangements affect how food is produced, processed, distributed and marketed, and the kind of food that is accessible influences nutritional quality. The assessment framework presented in this article focuses on these linkages, and thus on the governance of food systems and the effectiveness of food chain governance arrangements. In this article, governance relates to the process of governing food systems and the interplay between food system (or food chain) actors, that is the involvement of governmental institutions, nongovernmental organizations, civil society, and the private sector in decision-making processes that shape food systems (or food chains) and their development. Governance in this sense is the way rules, norms and actions are structured, sustained, regulated and implemented. The testing of the assessment framework shows how it can improve our understanding of agri-food chain governance arrangements. This in turn can inform the strategies of agri-food chain actors, administrations and policymakers aimed at a more efficient functioning of agri-food chains.

The two related research questions that we will address in this article are:

- What aspects need to be covered in a meaningful assessment of food chain governance arrangements?

- What indicators and variables can be used in assessing, monitoring and continuously improving food chain governance arrangements?

The article includes five sections beyond this first introductory section. Section Food chain governance provides a brief review of relevant conceptual frameworks and typology of food chain governance. Section Methodology and empirical basis covers the empirical basis for the analysis and the methodology. First, we briefly characterize and map the food chains in the six study regions. The literature review and the mapping of critical components of food chain governance provide the foundation for the elaboration of the indicator-based assessment framework of food chain governance. Section Toward an indicator-based assessment of food chain governance describes the assessment framework and key indicators for food chain governance arrangements. This section highlights indicator selection and information collection necessary for each key indicator to assess agri-food chain governance. The results of a first testing of the assessment framework in the six regions is presented in section Results of the first application of the assessment framework. The focus in the testing is on food chain governance objectives, the identification of conflicting goals, disconnects and tensions in food systems, and emerging opportunities and challenges. Contextual differences are considered. Section Conclusions concludes with a brief reflection on the strengths and weaknesses of the framework and the need for further research and testing.

\section{FOOD CHAIN GOVERNANCE}

\section{A Short Overview of Relevant Conceptual Frameworks}

Value chains encompass the organization, coordination and linkages, power dynamics, and governance between actors (Helmsing and Vellema, 2011; Ingram et al., 2018). Value chains foster the dynamic relationships and multi-actor interactions among the diverse actors involved in production to consumption activities for value creation and market linkages (Ayele et al., 2012), through knowledge exchange, information sharing, capacity strengthening, joint learning, and continuous problem solving (Kilelu et al., 2017; Maestre et al., 2017). Peterson et al. (2001) distinguished five major governance structures, namely spot/cash markets, specification contracts, relationbased alliances, equity-based alliances, and vertical integration. In contrast to the classification by Peterson et al. (2001) and Gereffi et al. (2005) developed five types of global food chain governance-market, modular, relational, captive, and hierarchy-which range from low to high levels of explicit coordination and power asymmetry.

According to Trienekens (2011), different disciplines such as new institutional economics, social network theory, and supply chain management, have contributed to the development of value chain theory (Arato et al., 2017). The theory of new institutional economics suggests that the behavior of economic agents is influenced by the social and institutional environments in which they operate (Jordaan et al., 2014). The social environment refers to the social dynamics (i.e., customs, norms and traditions) within communities of actors, and the social capital of the individuals influences collective actions (Jordaan et al., 2014). The institutional environment contains the rules and regulations for creating order to protect individuals against opportunistic behavior, it also encompasses the incentives for guiding the behavior of economic agents (Milagrosa, 2007; Ouma et al., 2017).

However, institutional economics has been criticized since it ignores the informal, socially embedded relationships in producing stable contract conditions (Demsetz, 1988). Social 
relationships, such as network and trust, play a very important role in shaping value chains, e.g., in the context of Asian culture and relationship exchanges (Zhang and Aramyan, 2009). Social network theory explains how aspects such as trust and reputation, beyond economic considerations, shape value chains and influence the structure and length of value chains (Trienekens, 2011).

Although supply chain management was argued to pay little attention to supply chain governance (Vlachos, 2014), supply chain management theory has contributed to the development of value chain theory. Some studies show that value chain governance is equivalent to supply chain governance, which refers to the rules, structures, and institutions that guide, control, and lead supply chains, providing the framework within which supply chain transactions are negotiated and executed (Vlachos, 2014; Amentae et al., 2018).

Management, as used in this paper, relates to entrepreneurial tasks and decisions that relate to the functioning of a business or a food chain. It comprises processes of planning, decision-making, organizing, leading, controlling human resources, financial, physical, and information resources to reach goals efficiently and effectively. Food (supply) chain management encompasses all activities that move food from production to consumption, including production, storage, distribution, processing, packaging, retailing, and marketing. The management decisions made by the respective actors at the different stages of a chain have implications for other stages. They influence the types of food available and accessible, as well as the way they are produced and consumed, and thus the nutritional value of the food produced. However, and as indicated earlier, in this paper, we focus on governance and the process of governing food systems and chains, and the way different actors shape food systems, food chains and their development.

\section{Types of Agri-Food Chain Governance Arrangements}

Many studies on food chain governance have examined informal socio-cultural factors, governance structures and dynamics, and intra-chain relationships and the distribution of power (Milagrosa, 2007; Oro and Pritchard, 2011; Hattersley, 2013; Jordaan et al., 2014; Abel et al., 2019). Agri-food chains are unique and differentiated from other product chains largely due to the perishable nature of inventory and seasonality, which significantly affects the logistics of each stage in the food chain, and due to special consumer demands for food safety and quality (Kline et al., 2016). The whole chain faces both general risks and unique vulnerabilities because of the limited shelf life of food, and variability in quality and availability of raw materials (Stone and Rahimifard, 2018).

Several studies adopted a wider perspective on food system governance, including the role of the institutional environment (Tallontire et al., 2011; Arato et al., 2017; Guéneau, 2018). Arato et al. (2017) adapted the Rural Web analysis, which has been elaborated by Van der Ploeg and Marsden (2008) as an approach to sustainable rural development, to the analysis of food chain governance. The strength of this wider approach is that the interconnections between six different dimensions including sustainability, novelty production, endogeneity, social capital, new institutional arrangement, and the governance of markets are explicitly considered. This in turn facilitates more encompassing strategies for the integration of small producers into local, regional, national and international markets while simultaneously enhancing rural livelihoods (Arato et al., 2017). Tallontire et al. (2011) and Guéneau (2018) suggest that the interplay between actors who are not directly involved in the chain may have important influence on governance, and that this should be taken into account (an example of this is the emergence of Private Sustainability Initiatives through roundtables, steering councils and other multi-stakeholder platforms).

Agri-food chains have food quality and safety characteristics that can contribute to credibility and consumer acceptance. Examples are food safety, healthy and nutritional food, authenticity, sustainable production processes and Fair Trade (Gachukia, 2015). Third party certification helps to guarantee these requirements (Gachukia, 2015). It also enhances risk management and fosters collaboration among food chain actors (Leat and Revoredo-Giha, 2013). The emergence of Alternative Food Networks (AFNs), such as communitysupported agriculture, farmer's markets, producer and consumer cooperatives, regional and local food hubs, is expected to improve both environmental and socio-economic aspects of food provisioning in terms of rural development, consumers' needs, and sustainable modes of production (Renting and Marsden, 2003; Knickel et al., 2008; Berti and Mulligan, 2016; Bui et al., 2019; Sureau et al., 2019). AFNs are generally perceived as coexisting with and in opposition to mainstream food chains characterized by industrialization and standardization. Priorities of AFNs are different in terms of supporting diversity, de-concentration in the food sector, and reconnecting food to socio-cultural and physical territorial contexts (Bui et al., 2019).

In view of our focus on Sub-Saharan Africa (SSA), smallholder inclusion and rural livelihoods are key dimensions in a meaningful assessment of governance arrangements. AFNs are characterized by collective action and they play an important role in integrating smallholders into high quality, high value food markets (Knickel et al., 2008; Yang et al., 2018). Likewise, the inclusive supply chain model helps address the challenges of integrating the poor in value chains (FAO, 2014). Through horizontal coordination, smaller food chain actors perform collective actions to reduce difference in power between actors and lower transaction costs (FAO, 2014). Inclusive business is a powerful way of helping drive economic opportunities for small-scale farmers, local and small agribusinesses, and the rural unemployed who would otherwise be left behind (Achterbosch et al., 2014). Ouma et al. (2017) suggested that horizontal integration of smallholder pig producers in Uganda into collectives helps improve their bargaining power and reduce transaction costs. Knickel et al. (2008) also demonstrated that European farmers benefit from collective action due to the growing power of retailers and the pressure resulting from the decline of producer prices and agricultural subsidies. Ros-Tonen et al. (2015) add that inclusive food chain collaboration also 
TABLE 1 | Agri-food chain governance arrangements that aim at meeting multiple objectives.

\begin{tabular}{|c|c|c|}
\hline Agri-food chain governance & Objectives of governance arrangements & Sources \\
\hline $\begin{array}{l}\text { Grounding of food chains in wider } \\
\text { sustainable rural development initiatives } \\
\text { (rural web) }\end{array}$ & $\begin{array}{l}\text { Governance arrangements reflect wider sustainability goals while } \\
\text { emphasizing novelty production, endogeneity, social capital, new } \\
\text { institutional arrangements, and the governance of markets as key leverage } \\
\text { points. }\end{array}$ & $\begin{array}{l}\text { Van der Ploeg and Marsden, } \\
\text { 2008; Arato et al., } 2017\end{array}$ \\
\hline $\begin{array}{l}\text { Private sustainability initiatives and other } \\
\text { multi-stakeholder initiatives }\end{array}$ & $\begin{array}{l}\text { Private sustainability initiatives aim at a wider adoption of sustainable } \\
\text { production standards and at including actors who are not directly involved } \\
\text { in food chains in initiatives, thereby fostering multiactor collaboration. }\end{array}$ & $\begin{array}{l}\text { Tallontire et al., 2011; } \\
\text { Guéneau, } 2018\end{array}$ \\
\hline Alternative Food Networks & $\begin{array}{l}\text { Improvement in both environmental and socio-economic aspects of food } \\
\text { provisioning, such as community-supported agriculture, farmer's markets, } \\
\text { and producer and consumer cooperatives. }\end{array}$ & $\begin{array}{l}\text { Renting and Marsden, 2003; } \\
\text { Berti and Mulligan, 2016; Bui } \\
\text { et al., 2019; Sureau et al., } \\
2019\end{array}$ \\
\hline $\begin{array}{l}\text { Inclusive business models and agri-food } \\
\text { chain arrangements }\end{array}$ & $\begin{array}{l}\text { Integrating smallholder farmers, small local agribusinesses, rural } \\
\text { unemployed, and the poor in value chains and improving access to } \\
\text { markets. Inclusive value chains tend to increase smallholder productivity } \\
\text { and market integration. }\end{array}$ & $\begin{array}{l}\text { Knickel et al., 2008; } \\
\text { Achterbosch et al., 2014; } \\
\text { FAO, 2014; Ros-Tonen et al., } \\
\text { 2015; Ouma et al., } 2017\end{array}$ \\
\hline
\end{tabular}

fosters adaptive learning and empowerment processes related to smallholder productivity and market integration.

Based on the above, we can summarize the range of objectives that can relate to alternative food chain governance arrangements (Table 1).

\section{METHODOLOGY AND EMPIRICAL BASIS Approach and Data Collection}

The elaboration of the framework for assessing food system governance arrangements that we present in this article is based on six urban and peri-urban regions in Sub-Saharan Africa (SSA): Cotonou (Benin), Bahir Dar (Ethiopia), Kisumu (Kenya), Rwamwanja (Uganda), and Lusaka and Chongwe (both in Zambia). When selecting the cases for studying food chain governance arrangements, attention was paid to ensure diversity in the following key criteria:

- Lead actor/initiator, e.g., civil society organizations, farmers association, processor, retailer: The cases are led by a range of food chain actors that play key role in food chain functions from production, processing, distribution to consumption. Particular attention was paid to fostering healthy and nutritious food products. The cases comprise food production and marketing activities related to maize, legumes, traditional leafy vegetables, fruits, street fresh foods. Local consumption and consumers are covered as well as questions related to the empowerment of small and middle-sized farms, processors and retailers.

- Coverage in terms of geography, food chain governance arrangements, institutional, economic, environmental and social conditions: In terms of geographical locations, the six cases cover a wide spectrum of food systems and contexts: three in East Africa (Rwamwanja Refugee Settlement-Uganda; Kisumu County- Kenya, and Bahir Dar city- Ethiopia), one in West Africa (Cotonou, Littoral Department- Benin) and two in Southern Africa (Chongwe and Lusaka Districts- Zambia). The various locations and makeup of each case will allow cross-cases exchange and learning as well as answering specific questions about food system governance, technology, policy frameworks, consumer choices and preferences.

- Innovativeness of the initiative and learning potential: Each case study focuses on reconnecting sustainable food production with (urban) food consumption, healthy diets, and the related local food system challenges. All case studies are driven by practice partners, with researchers being in an accompanying, facilitating role. Other key criteria were unique local knowledge and expertise; space for experimentation, innovation and transformation; application of new knowledge, co-learning and the formation of new, collective insights.

The mapping (and assessment presented later) was supported by local partners. During scheduled meetings, focus group discussions were carried out. Guidelines and a checklist were developed and shared with local partners to provide background information on the study and to ensure the comparability of the data collected. Guidelines and checklist related to the key products for the region, the processes and actors involved in the value chain, product and geographical mapping, and food system governance related information. The focus groups in each region included researchers, social entrepreneurs, farmers, consumers, food businesses and policy makers as key stakeholders. Where gaps remained, additional data was obtained through a smaller number of online calls (due to travel restrictions in place during the study period).

The six urban and peri-urban regions in SSA and related local partners are summarized in Table 2.

\section{Characterization of the Six Study Regions and Main Food Chains}

In the following, we map the status-quo of key agrifood chains in the six regions. The mapping provides the basis for the subsequent assessment of agri-food chain governance arrangements. 
TABLE 2 | Study areas and food chains investigated.

\begin{tabular}{|c|c|c|}
\hline Region & Food chain studied & Local partner \\
\hline Rwamwanja Refugee Settlement, southwest Uganda & Maize, legumes & Finn Church Aid \\
\hline Chongwe District, Lusaka Province, Southeast Zambia & Vegetables & Hivos \\
\hline Lusaka city, Lusaka Province, Southeast Zambia & Vegetables, street fresh foods & Hivos \\
\hline Kisumu County, western Kenya & Fish, traditional leafy vegetables & Bioversity International, Kenya \\
\hline $\begin{array}{l}\text { Bahir Dar city and Koga irrigation area, Amhara Regional State, } \\
\text { North Ethiopia }\end{array}$ & Legumes, vegetables, fruits, fish & Bahir Dar University \\
\hline Cotonou, Littoral Department, South Benin & Leafy vegetables, carrots & University of Abomey-Calavi \\
\hline
\end{tabular}

\begin{tabular}{|c|c|c|c|c|}
\hline $\begin{array}{l}\text { Only two stages: } \\
\text { - production } \\
\text { - marketing } \\
\text { Main actors: } \\
\text { - producers } \\
\text { - middlemen } \\
\text { - transporters } \\
\text { - traders } \\
\text { - consumers }\end{array}$ & $\begin{array}{l}\quad \text { Production } \\
\text { - Women farmers } \\
\text { maize and sell off } \\
\text { once after the drying } \\
\text { season. } \\
\text { - There is no } \\
\text { processing value- } \\
\text { added } \\
\text { - Low producer price } \\
\text { - Production decision } \\
\text { made by man in a } \\
\text { family } \\
\text { Producers } \rightarrow\end{array}$ & $\begin{array}{l}\quad \text { Processing } \\
\text { A few small-scale } \\
\text { maize processors } \\
\text { using very small } \\
\text { grinding mills } \\
\text { Located in the refugee } \\
\text { settlement and a few } \\
\text { are outside } \\
\text { They grind maize } \\
\text { mainly for the } \\
\text { households' food } \\
\text { consumption }\end{array}$ & $\begin{array}{l}\text { Distribution } \\
\text { Local middlemen are } \\
\text { resident in the } \\
\text { refugee settlement } \\
\text { - Others are part of the } \\
\text { business community } \\
\text { in the settlement and } \\
\text { surrounding trading } \\
\text { centres } \\
\text { - Transporters } \\
\text { - Traders } \\
\text { Retailors/Wholesalers } \\
\rightarrow\end{array}$ & 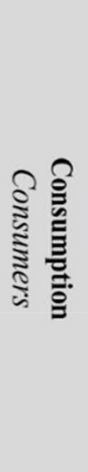 \\
\hline \multicolumn{5}{|c|}{ 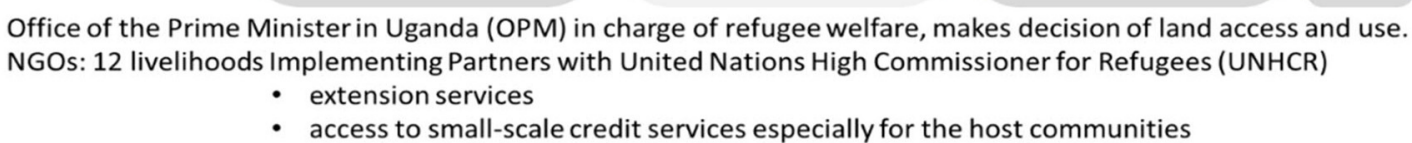 } \\
\hline
\end{tabular}

FIGURE 1 | The status quo of maize value chain in Rwamwanja refugee settlement.

\section{Rwamwanja}

Rwamwanja works with women farmers to transform the maize value chain so that they can better benefit from maize production. Legume production is also encouraged to provide farmers with access to nutritious food and generate a more environmentally sustainable and diverse production. The current maize value chain is highly concentrated with intermediaries who reduce potential profits to farmers and there are a few small-scale maize processors using very small grinding mills. Some NGOs, termed as Implementing Partners with United Nations High Commissioner for Refugees, are connected to the maize value chain activities through various thematic programs working with the refugees and local host community and through providing extension services. The status quo of the maize value chain in Rwamwanja is shown in Figure 1.

\section{Chongwe}

Chongwe focuses on vegetable production, especially by women, with a high scale production of tomato, cabbage, pumpkin leaves and Chinese cabbage in the area. Constraints in local vegetable value chains emanate from a lack of water and various inputs, limited use of sustainable agricultural practices, and high transportation costs and post-harvest losses. Farmer cooperatives and trader associations are encouraged to be introduced to empower farmers and increase their knowledge. The status quo of vegetables value chain in Chongwe is shown in Figure 2.

\section{Lusaka}

Lusaka works with the informal food sectors (IFS) for improved diets and nutrition. Lusaka focuses on value chains of vegetables and fresh foods, and works with market traders/vendors, and those working in organized nutrition groups with simple technologies for fresh foods and vegetables to preserve and increase shelf life. The main constraints include lack of capacity building and formal recognition. In addition, there are inadequate storage facilities, inadequate market information on prices, disconnection from farmers/producers that is exacerbated by middlemen. The status quo of informal food sector in diets and nutrition chain in Lusaka is shown in Figure 3.

\section{Kisumu}

Kisumu focuses on fish and traditional leafy vegetables (TLV), which have relatively short value chains. Men are predominantly involved in the fish value chain. In the vegetable value chain, women are involved in the farming and trading, while men are engaged in the transportation. The status quo of fish and TLV value chains is shown in Figure 4. 


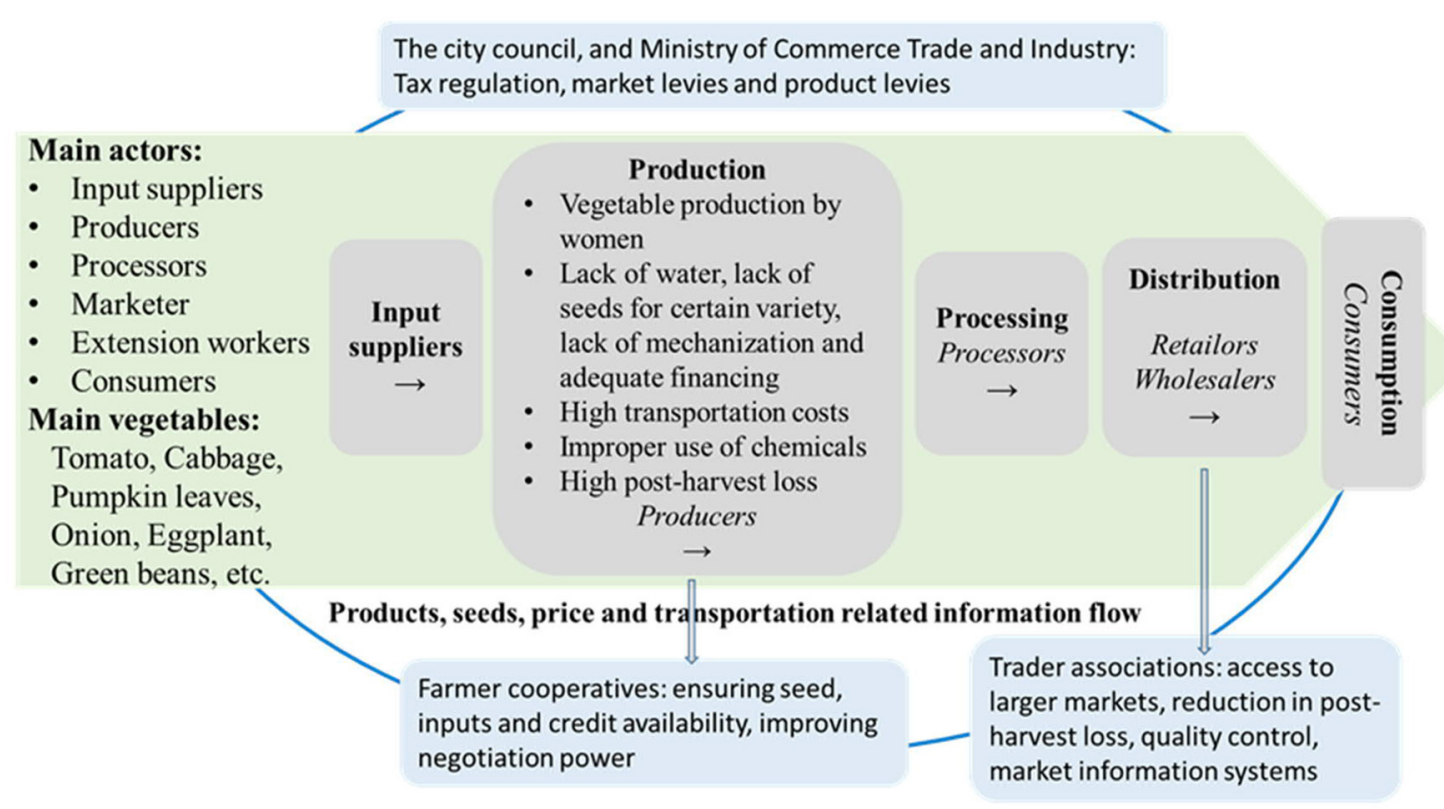

FIGURE 2 | The status quo of vegetables value chain in Chongwe.

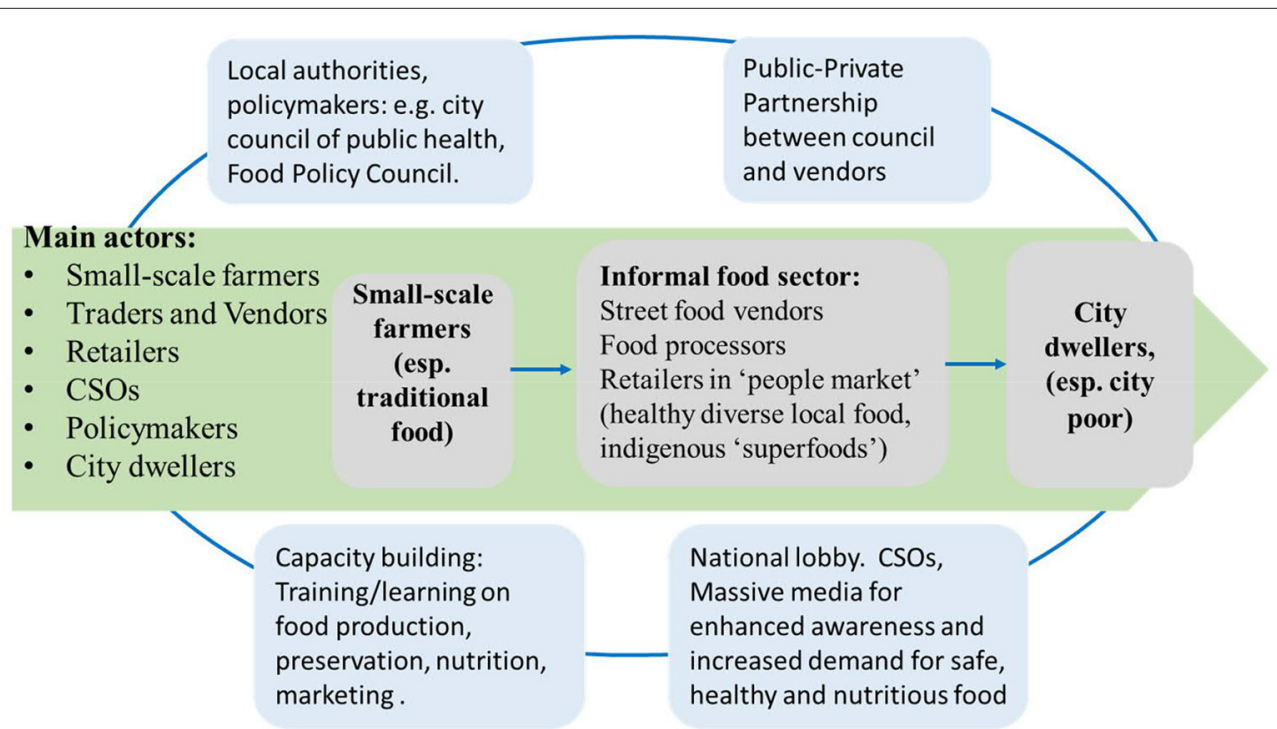

FIGURE 3 | The status quo of informal food sector in diets and nutrition chain in Lusaka.

\section{Bahir Dar}

Bahir Dar mainly deals with four products: fish, vegetables (onion, tomato, pepper, cabbage, swiss chard and carrot), fruits (strawberry and avocado) and legumes (soybean, lupine, field pea and broad beans). In general, governmental and nongovernmental organizations provide support for infrastructure development. Banks, microfinance institutions and informal credit suppliers support financial and public extension services. Insurance companies are not involved in any of the value chains. The vegetable and fruit productions are subject to input supply problems, high prevalence of disease and insect pests, marketing problems, and improper agronomic practices. For the fish value chain, the presence of illegal fishers with small sized mesh leads to a reduction of fish stocks and species diversity, and the main constraints include absence of shade for fish processing on the beach and marketplace, lack of adequate freezing equipment, and low fish demand and price fluctuation resulting from religious fasting days. The status quo 


Stages:
- Production
- Transportation
- Trading
- Consumption
Main actors:
- Farmers
- Middlemen(Transporters)
- Processors
- Traders
- Consumers

Stages:

- Transportation

- Trading

- Consumption

Main actors:

- Farmers

- Middlemen(Transporters)

- Traders

- Consumers

\section{Production}

- Men fish farmers and women vegetable farmers

- Harvest and grade, and unload fish off the vessel

- Produce, grade, and bulk the vegetables

Producers $\rightarrow$
- Middlemen (transporters) from the fishing sites or vegetables farm to the market

- Wholesalers and retailers purchase fish or vegetables from farmers

- Exporters sale fish to external markets Middlemen/

Retailors/Wholesalers $\rightarrow$
Distribution

County government taxation: subjected to traders and commercial processors

FIGURE 4 | The status quo of fish and TLV value chains in Kisumu.

Main actors:

- Input suppliers

- Producers

- Middlemen

- Collectors

- Processors

- Transporters

- Traders

- Consumers

Main products: Fish

\section{Production}

- Fish primary process(clean, fillet, skinning and sort)

- Fish secondary process (grade, pack, storage)

- Fruits and vegetables (harvest, precool, sort, grade, wax, pack, storage) Producers $\rightarrow$

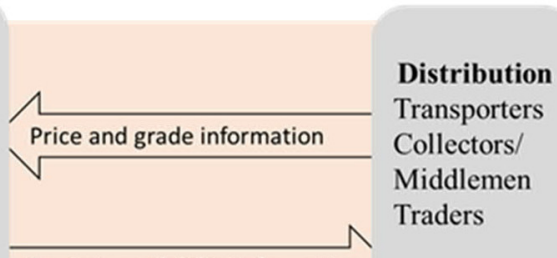

Product availability information

\section{Retailors \\ Wholesalers}

Vegetables Fruits $\rightarrow$

Some purchar from the traders or fish farmers

Processors $\rightarrow$

Legumes

Governmental and NGOs: infrastructure development

Banks, microfinance institutions and informal credit suppliers: financial capacity building

Research and higher learning institutions: developing and distributing technologies.

Government extension services: distributing technologies and training services.

FIGURE $\mathbf{5}$ | The status quo of fish and vegetables, fruits, legumes value chains in Bahir Dar.

of fish and vegetables, fruits, legumes value chains is shown in Figure 5.

\section{Cotonou}

Cotonou works on the diets of children and adolescents through urban farming in a peri-urban area. The main products are leafy vegetables (LFs) and carrots in urban farms, both of which are mostly sold fresh, with less conservation, packaging and transformation (powdering, drying of LFs and mashing of carrots). The constraints include poor quality of seeds used, poor use of chemical fertilizers and phytosanitary products, and lack of storage methods for vegetables. The status quo of LFs and carrot value chains is show in Figure 6.

\section{Key Components of Governance Arrangement Based on the Previous Findings}

According to the findings on food chain governance (specifically Milagrosa, 2007; Oro and Pritchard, 2011; Hattersley, 2013; Jordaan et al., 2014; Abel et al., 2019), critical components of governance arrangements can be identified. They include the institutional environment, socio-cultural factors, governance structures and dynamics, and intra-chain relationships and power.

In line with this, we can identify the following key areas for our assessment framework: 


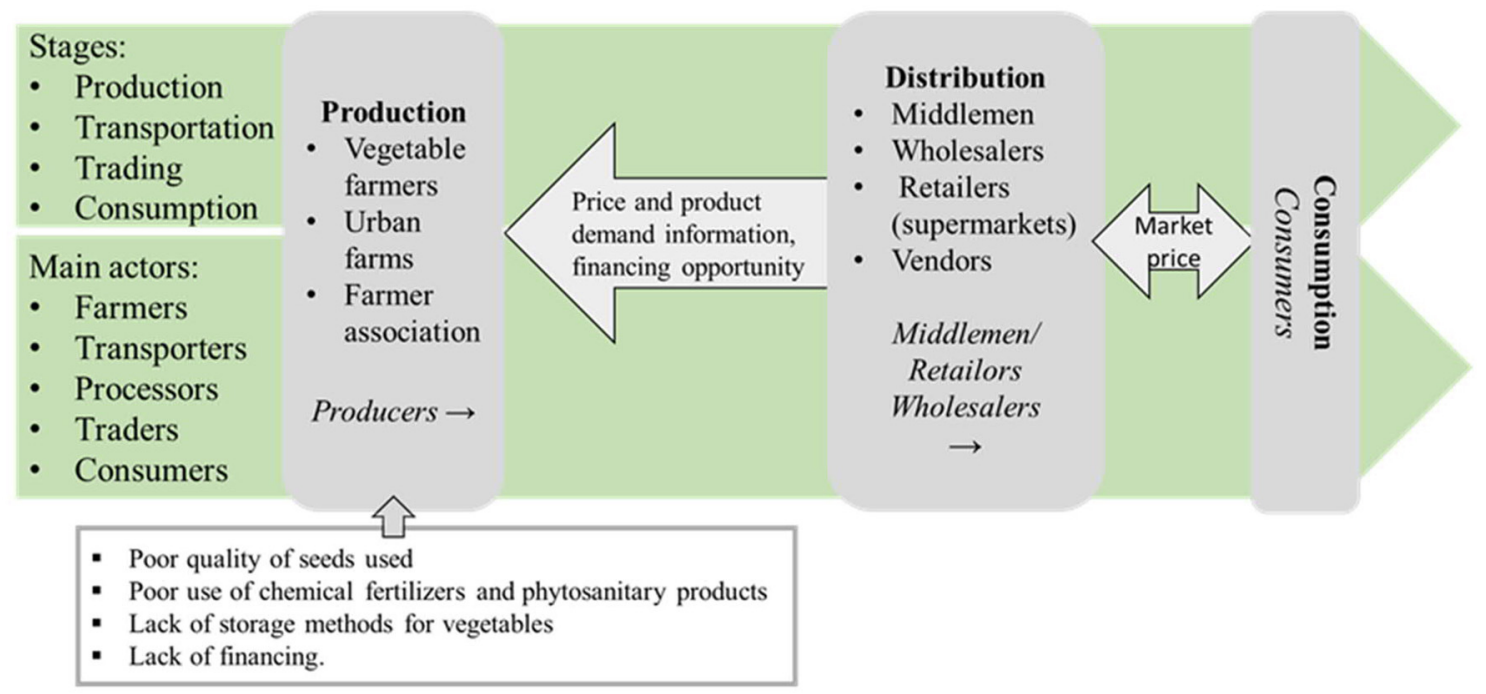

FIGURE 6 | The status quo of LFs and carrot value chains in Cotonou.

a) Enabling environment and institutions: socio-cultural factors (informal, e.g., customs, traditions, and social norms), formal institutional elements (rules, regulation, law, and legislations), organizational elements, and infrastructural elements.

b) Governance structures: cash markets, contracts, relation-based alliances, equity-based alliances, and vertical integration.

c) Governance structure dynamics: complexity of transactions, ability to codify transactions, capabilities in the supply-base.

d) Governance structure and relationship strength: mutual understanding, trust, commitment, symmetry, and power.

In addition to these four areas, attention needs to be paid to the objectives of agri-food chain governance in the six regions: sustainability, healthy and nutritious food products for local consumers, empowering small and middle-sized farms, processors, and retailers. The common challenges in these six regions include heavy reliance on cereal-based food products, low accessibility to and consumption of nutritious food such as fruits, vegetables, fish and flesh foods, non-sustainable vegetable production, inadequate storage facilities and high post-harvest losses, limited availability of market information, and low productivity. Connected with these are high levels of malnutrition and food poverty. Related to food system governance, the relations between different sized farms, food SMEs, retailers and consumers are playing a central role.

\section{TOWARDS AN INDICATOR-BASED ASSESSMENT OF FOOD CHAIN GOVERNANCE}

\section{Structure of the Assessment Framework}

Figure 7 provides a summary overview of the resulting structure for the assessment framework. The food chain activities and relevant chain actors include production of food by farmers and cooperatives, processing/packaging of food by processors firms, distribution/marketing of food by middlemen, wholesalers and retailers, and consumption of food by consumers.

\section{Indicator Selection and Data Required}

Based on the above and the results of our literature review, we will in the following identify key indicators on enabling environment and institutions, governance structures, governance structure dynamics, and relationship strengths. The indicators ought to also reflect the objectives for the agri-food chain in six regions (i.e., sustainability, healthy and nutritious food products for local consumers, empowering small and middle-sized farms, processors and retailers).

When identifying suitable indicators, we also consider the commonly used requirements for indicators: valid, precise, practical, affordable and simple, reliable, sensitive, clear, useful and owned. Particular attention was paid to selecting indicators that will be useful for decision-making, foster accountability and learning; and that stakeholders think that their use makes sense.

Table 3 provides an overview of the indicators that have been selected. Each food chain governance aspect has between three and five indicators that can be monitored and assessed. Each indicator can be measured (or estimated) through one or more variables and may be expressed in quantitative and/or qualitative terms (e.g., low, medium, high).

In total there are total 15 indicators for the four dimensions of chain governance. The indicator of governance structure is underpinned by studies from Peterson et al. (2001) and Gereffi et al. (2005). As developed by Peterson et al. (2001) and Gereffi et al. (2005), the major hybrid forms of governance structures range from cash (or spot) markets at the one end and hierarchy or vertical integration at the other end, which vary considerably in levels of explicit coordination and power asymmetry. 


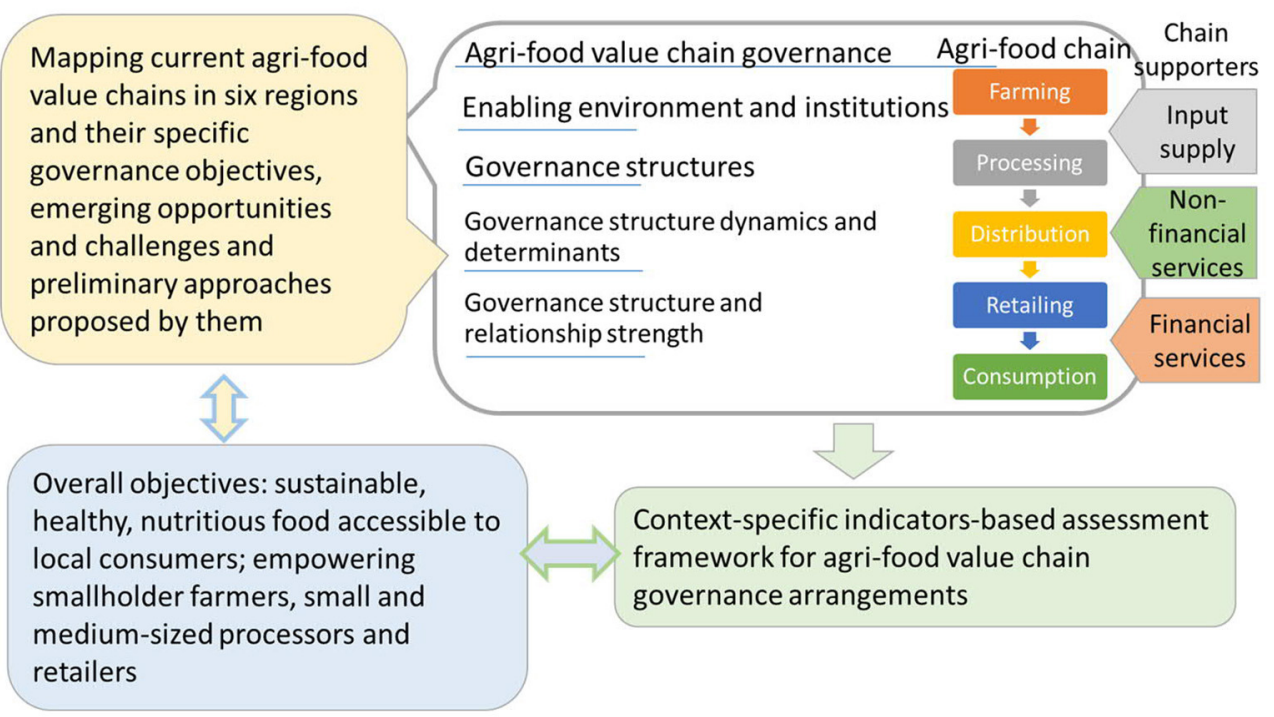

FIGURE 7 | Overview of the structure of the assessment framework.

Regarding the data required for each of these indicators, it should be noted that the detailed methods of monitoring and assessing the indicators will be further developed in consultation with local partners and relevant stakeholders in the six regions. The overview in Table 4 on the data collection required provided is indicative.

\section{RESULTS OF THE FIRST APPLICATION OF THE ASSESSMENT FRAMEWORK}

\section{Food Chain Governance Objectives, Challenges, and Opportunities}

In this section we present the results of a first application of the assessment framework in the six study regions. The aim is to check in how far the approach can help to identify conflicting goals, disconnects and tensions in food systems, and to formulate strategies for achieving more efficient, equitable and sustainable agri-food systems. It is expected that the testing can also provide indications for a further refinement of the framework.

The discussion builds on the characterization of the six study regions and main food chains in section Characterization of the six study regions and main food chains. Based on the structured interviews with various actors, including researchers, social entrepreneurs, farmers, activists, businesses and policy makers, and the focus group discussions, the collected data are synthesized to capture relevant information about food chain governance objectives, challenges and opportunities. The key question is in how far the food system changes proposed by key actors in the six regions can be corroborated using the assessment framework. To start with, challenges and opportunities are compared with envisaged changes (Table 5).

\section{Approaches Proposed to Food Chain Governance in the Study Regions}

In Table 6 we compare the food chain governance improvements proposed by regional actors with the criteria contained in the assessment framework. Overall, the proposed improvements by regional actors in response to the challenges they are confronted with, and their governance objectives mostly correspond to the indicators contained in the assessment framework. Especially the first dimension of an enabling governance environment, the third dimension of governance structure dynamics and the fourth dimension of the strength of relationships are important for regional food chain actors.

At the same time, we can see that Indicators 5, 6, and 7 in the second dimension relating to governance structures did not raise concerns in the proposed approaches in the study regions. Similarly, Indicator 1 'Socio-cultural factors (informal)', Indicator 3 'Non-market mechanisms (e.g., quality standards and initiatives)', and Indicator 15 'Multi-stakeholder platforms' (e.g., public campaigns on communication about healthy food and nutritious dietary patterns, platform on sustainable agri-food system) have not been reflected by regional food system actors.

In further work and discussions with regional actors, particular attention ought to be paid to these aspects, to a further substantiation of disconnects and tensions in given food systems, ways to address these in more transparent and equitable ways, and to a piloting of potential improvements.

\section{CONCLUSIONS}

The assessment framework elaborated in this article aims at strengthening the diversity, sustainability, resilience and connectivity of food systems. More specifically, it aims at improving food chain governance arrangements that play a 
TABLE 3 | Food chain governance dimensions, relevant indicators and variables.

\begin{tabular}{|c|c|c|}
\hline $\begin{array}{l}\text { Chain governance } \\
\text { dimensions }\end{array}$ & Purpose & Relevant indicators \\
\hline $\begin{array}{l}\text { Enabling } \\
\text { environment and } \\
\text { institutions }\end{array}$ & $\begin{array}{l}\text { To assess impact of } \\
\text { sociocultural and institutional } \\
\text { elements on agri-food value } \\
\text { governance }\end{array}$ & $\begin{array}{l}\text { 1. Socio-cultural factors } \\
\text { (informal). } \\
\text { 2. Laws and regulations. } \\
\text { 3. Non-market mechanism } \\
\text { (e.g., quality standards and } \\
\text { initiatives). } \\
\text { 4. Investment and finance } \\
\text { service (e.g., microfinance). }\end{array}$ \\
\hline
\end{tabular}

Governance structures

Governance structure dynamics and determinants
To identify the current main governance structures and its changing trends
To identify the main determinants affecting governance and configuration of agri-food chain, and to explore the influence of market power on agri-food chain governance
5. Spot/cash markets.

6. Contract governance (market contracts and production contracts, contract farming).

7. Relation governance (relation-based alliances; equity-based alliances; and vertical integration).

8. Access to information and knowledge.

9. Participation in partnership networks.

10. Competences of farmers and SMEs.

11. Price determination

12. Value-added.
Variables to measure the indicators

Relevant traditions and societal norms (correspond to indicator 1). Number of new regulations, incentives and programmes in sustainable food system development (corresponds to indicator 2). Presence of food policies and programmes on environmental sustainability and social inclusion (corresponds to indicator 2). Presence of local food initiatives and practices relevant to food safety, quality, and nutrition (corresponds to indicator 3). Investments in agri-food sector infrastructure (storage facilities, transport facilities and wholesale markets) (corresponds to indicator 4). Level of microfinance for smallholders (corresponds to indicator 4).

Market share of spot market (i.e., commodities are traded for immediate transaction in market) governance (corresponds to indicator 5).

Market share of contract governance (corresponds to indicator 6). Market share of long-term relationship (including relation-based alliances, equity-based alliances, and vertical integration also included here. e.g., joint ventures, strategic partnerships between suppliers and buyers, technology licensing, and alliances) governance structure (corresponds to indicator 7).

Application of information communication (e.g., the integration of smart phone-based and internet-based interpersonal communication with conventional and new media channels enables to create more opportunities to access agricultural technological and market information, to share experience and knowledge, and user-friendly technology) (corresponds to indicator 8).

Information available about resources to agri-food programs and plans (corresponds to indicator 8).

Training activities (corresponds to indicator 8).

Level and effectiveness of participation in partnership networks (corresponds to indicator 9).

Suppliers' competences (corresponds to indicator 10).

Premium price of agricultural products (e.g., premium price as result of building storage center for non-harvest season and label for regional, premium quality or organic production) (corresponds to indicator 11). Value-added along food chain (e.g., adding value through building processing center and package center) (corresponds to indicator 12). Type and frequency of multi-actor collaboration (e.g., collaboration between farmers, seed companies, research centers, urban market, vendors) (corresponds to indicator 13).

Form and number of cooperatives and associations (e.g., registered maize farmers, registration of producer associations, cooperatives, aggregation, and collective marketing) (corresponds to indicator 14). Number of public campaigns on communication and public awareness about sustainable, healthy, and nutritious food (corresponds to indicator 15).

Change in consumers' behaviors toward healthy and nutritious food choices and their dietary patterns (corresponds to indicator 15). Multi-stakeholder platforms on sustainable agri-food system (e.g., multi-stakeholder dialogue platform among representatives from relevant ministries, research centers, extension centers, agricultural education institutions, civil society, farmer organization and agri-food companies) (corresponds to indicator 15). central role in connecting sustainable, resilient farming with healthy nutrition.

Key actors in all six regions aim at improving food chain governance. The main goals of the related changes are:

- boosting the productivity of rural smallholder maize farmers (in Rwamwanja, Uganda),
- enhancing sustainable legume, vegetable and fruit production and fish value chains for diverse, safe, healthy, nutritious, and affordable food for the urban poor (in all six regions),

- improving child nutrition via school gardens and urban farming (in Cotonou, Benin), 
TABLE 4 | Information collection for each indicator.

\begin{tabular}{|c|c|c|}
\hline Specific indicators & Information to be collected & Methods \\
\hline Informal sociocultural elements & Relevant traditions and societal norms & Literature review and screening of legislative texts. \\
\hline Law and regulations & $\begin{array}{l}\text { New regulations, policies, incentives and programmes in } \\
\text { sustainable and healthy food system development }\end{array}$ & \\
\hline Non-market mechanism & $\begin{array}{l}\text { Effect of standards guaranteed by third party and local } \\
\text { food initiative }\end{array}$ & $\begin{array}{l}\text { Secondary statistical data. } \\
\text { Targeted primary data collection. }\end{array}$ \\
\hline Investment and finance service & $\begin{array}{l}\text { Effect of microfinance and investment in sector } \\
\text { infrastructure }\end{array}$ & Key person interviews. \\
\hline Spot/cash markets & Spot market share and type & \\
\hline Contract governance & Contract governance share and type & \\
\hline Relation governance & Relation governance share and type & \\
\hline Access to information and knowledge & Application of IC tools; Training for chain actors & \\
\hline Participation in partnership networks & Participation rate in networks & \\
\hline Competences by farmers and SMEs & Change in supply competence & Pilot actions and related monitoring. \\
\hline Price determination & Market power in pricing & $\begin{array}{l}\text { Statistical data. } \\
\text { Targeted primary data collection. } \\
\text { Key person inter-views. }\end{array}$ \\
\hline Value-added & Quantifying value-added & \\
\hline $\begin{array}{l}\text { Linkages between chain actors and } \\
\text { disconnects }\end{array}$ & Coordination types & $\begin{array}{l}\text { Pilot actions and related monitoring. } \\
\text { Targeted primary data collection. }\end{array}$ \\
\hline Cooperatives and associations & Scales in cooperatives and associations & Key person inter-views. Focus groups. \\
\hline Multi-stakeholder platform & $\begin{array}{l}\text { Capacity in multi-stakeholder platform such as public } \\
\text { campaigns, mass media, consumers' preference on and } \\
\text { food suppliers' manner in healthy food }\end{array}$ & \\
\hline
\end{tabular}

- enhancing capacity building in food traders and vendors (in Lusaka, Zambia),

- developing more efficient market linkages for healthy food (in all six regions), and

- helping the rural, urban, and peri-urban poor change their eating habits toward a healthier pattern (in all six regions).

Based on a first testing of the framework, we could identify three key aspects:

- First, context-specific policies and programmes relevant to sustainable food system and food chain governance are of significance. The relevant indicators we selected include changes in new regulations in sustainable food system development, food policies and programs on environmental sustainability and social inclusion, local food initiatives and practices relating to food safety, food quality and nutrition, and investments in agri-food sector infrastructure, such as storage facilities, bulking and processing centers, transport facilities and wholesale markets. Lack of storage facilities, transportation and road infrastructure overwhelmingly affects smallholders in most SSA countries, making it difficult to sell their products at fair market prices and impeding reaching markets and consumers. Food safety control is expected to protect consumers through establishing a monitoring system that reduces chemical and microbiological contamination and enables the addition of micronutrients into foods during processing. Meanwhile, mandatory labeling and standards can reduce unhealthy food availability in the food supply.
An inclusive dialogue and nutrition strategy at various government levels can ensure food to be produced, distributed, and consumed in a sustainable manner and contribute to improved nutrition.

- Secondly, the indicators concerning governance structure transformation's determinants have been highlighted. Indeed, suppliers are empowered along the agri-food chain and their competences are developed when there are changes in capacity building for food suppliers (farmers, processor, and retailers), such as improved application of information communication, more extensive training activities, and enhanced farmer connectivity to markets. Information technology is of increasing importance in business activities associated with delivering nutritious food to markets, e.g., the emergence of ecommerce, as price premiums and high value-added for food suppliers is more likely. In addition, supermarkets and street food vendors play a particularly important role in delivering more nutritious and fresh local food at affordable prices to consumers.

- Thirdly, some important indicators embody multi-actor collaboration, cooperatives and associations, and multistakeholder platforms on sustainable agri-food system. On one hand, it is widely recognized that farmer cooperatives, third party certification bodies, other associations, and partnership networks enable smallholders to have stronger bargaining power at markets. On the other hand, large-scale public education on nutrition and mass media campaigns can enhance consumers' nutrition awareness and influence 
TABLE 5 | Food chain governance challenges, opportunities, objectives and envisaged changes.

\begin{tabular}{|c|c|c|c|}
\hline Region & Challenges / opportunities & $\begin{array}{l}\text { Food chain governance } \\
\text { objectives }\end{array}$ & Envisaged changes \\
\hline $\begin{array}{l}\text { Rwamwanja refugee } \\
\text { settlement } \\
\text { (SW-Uganda) }\end{array}$ & $\begin{array}{l}\text { Support self-sufficiency and } \\
\text { community-based extension. } \\
\text { Empower women and train } \\
\text { smallholders to improve their } \\
\text { productivity, quality, and } \\
\text { sustainable production. } \\
\text { Boost market access \& } \\
\text { income generation. }\end{array}$ & $\begin{array}{l}\text { Boost productivity and } \\
\text { improve agri-food chain } \\
\text { governance of rural } \\
\text { smallholder maize farmers. } \\
\text { Legume production } \\
\text { introduced for more nutritious } \\
\text { and healthier food and } \\
\text { environmental sustainability. }\end{array}$ & $\begin{array}{l}\text { Farmer groups to produce maize. } \\
\text { Establish a processing (grinding meal) center. } \\
\text { Improve maize packaging and labeling. } \\
\text { Facilitate marketing at better prices by direct linkages between } \\
\text { farmers and buyers. } \\
\text { Put in place chicken feed production facilities. }\end{array}$ \\
\hline $\begin{array}{l}\text { Chongwe } \\
\text { (SE-Zambia) }\end{array}$ & $\begin{array}{l}\text { Access to markets by } \\
\text { vegetable producers. } \\
\text { Training for farmers on } \\
\text { sustainable farming practices. }\end{array}$ & $\begin{array}{l}\text { Foster vegetable production } \\
\text { for a sustainable food system. } \\
\text { Improve vegetable chains } \\
\text { through participatory } \\
\text { multi-actor approach. }\end{array}$ & $\begin{array}{l}\text { Ensure seeds and other inputs and credit availability and training. } \\
\text { Facilitation of bulking through the functioning of cooperatives to } \\
\text { access to larger markets. } \\
\text { Reduction of post-harvest losses. } \\
\text { Strengthen relationship between farmer cooperatives, trader } \\
\text { associations, city council and Ministry of Commerce Trade } \\
\text { and Industry. }\end{array}$ \\
\hline Lusaka (SE- Zambia) & $\begin{array}{l}\text { Stunting/ lack of dietary } \\
\text { diversity. } \\
\text { Access healthy/safe food } \\
\text { through food vendors. } \\
\text { Training on food safety. }\end{array}$ & $\begin{array}{l}\text { Capacity building, formal } \\
\text { recognition and participation } \\
\text { of food traders and vendors. } \\
\text { Enhance role of informal food } \\
\text { sector and boost local } \\
\text { economic activity. }\end{array}$ & $\begin{array}{l}\text { Promote simple food preservation technologies to enable long } \\
\text { shelf life. } \\
\text { Increase the availability of market information. } \\
\text { Acknowledge the role of the informal food sector through } \\
\text { government institutions. }\end{array}$ \\
\hline $\begin{array}{l}\text { Kisumu County } \\
\text { (W-Kenya) }\end{array}$ & $\begin{array}{l}\text { Nutritious diets for urban } \\
\text { dwellers. } \\
\text { Support to fish and leafy } \\
\text { vegetable production. } \\
\text { Capacity of farmers and } \\
\text { consumers improved } \\
\text { through training. }\end{array}$ & $\begin{array}{l}\text { Enhance leafy vegetables and } \\
\text { fish value chains for diverse, } \\
\text { safe, nutritious, and affordable } \\
\text { food for urban poor. }\end{array}$ & $\begin{array}{l}\text { Farmer cooperatives. } \\
\text { Facilitation of bulking. } \\
\text { Cool chain for reduction of post-harvest losses. }\end{array}$ \\
\hline $\begin{array}{l}\text { Bahir Dar (NW- } \\
\text { Ethiopia) }\end{array}$ & $\begin{array}{l}\text { Declining production of } \\
\text { nutritious food stuffs due to } \\
\text { soil depletion. } \\
\text { Priority put on (tree) } \\
\text { cash-crops. } \\
\text { New approaches to } \\
\text { vegetable, legume and small- } \\
\text { scale fish production. }\end{array}$ & $\begin{array}{l}\text { Improve supply, marketing, } \\
\text { and utilization of nutritious } \\
\text { foodstuffs in urban and } \\
\text { peri-urban Bahir Dar. } \\
\text { Mixed systems to improve } \\
\text { profitability and performance } \\
\text { of local agri-food economy. }\end{array}$ & $\begin{array}{l}\text { Development of infrastructures and extension services. } \\
\text { Cold chain management for reduction of post-harvest losses. } \\
\text { Development of processing industry. } \\
\text { Introduction of contract farming. } \\
\text { Strengthening of farmer's marketing cooperatives. } \\
\text { Improve the availability of credit. } \\
\text { Improve the rules and regulations of fishing. } \\
\text { Develop a buffer zone of lakes. }\end{array}$ \\
\hline Cotonou (S-Benin) & $\begin{array}{l}\text { Malnutrition and obesity } \\
\text { among children. } \\
\text { Improved awareness of } \\
\text { nutritious food. } \\
\text { Establish school gardens. } \\
\text { Direct links between farmers } \\
\text { and food programs. }\end{array}$ & $\begin{array}{l}\text { Improve child nutrition via } \\
\text { school gardens and urban } \\
\text { farming in peri-urban } \\
\text { Cotonou. } \\
\text { Develop more efficient market } \\
\text { linkages for healthy food. }\end{array}$ & $\begin{array}{l}\text { Promotion and facilitation of access to improved seed use, use of } \\
\text { manure and organic phytosanitary products. } \\
\text { Development of technologies for vegetable conservation. } \\
\text { Provision of financial opportunities such as microfinance. }\end{array}$ \\
\hline
\end{tabular}

consumer behavior toward healthier food choices. A multistakeholder platform, e.g., making nutritious food more accessible in public procurement, and farm to school programs like school gardens for more provisioning of nutritious foods, can facilitate accessibility to healthy food. Additionally, effective outreach is crucial, e.g., mass media campaigns, NGOs, governments, engage to phase out advertising and promotion of unhealthy foods, especially to children and adolescents. Accordingly, enhanced nutrition awareness among actors along a food supply chain can motivate them to maximize nutrition entering the food chain.

Using the assessment framework, we could better understand present governance arrangements, conflicting goals, disconnects and tensions, and support their refinement. In conjunction with the piloting of changes in governance arrangements, the 15 indicators included in the framework can also be used to monitor the effectiveness of changes. In further work and discussions with regional actors, particular attention ought to be paid to governance structures (Indicators 5-7), as well as Indicator 1 'Socio-cultural factors (informal)', Indicator 3 'Non-market mechanisms', and Indicator 15 'Multi-stakeholder platforms. Related to these platforms and actor relationships in food chains, it seems important to pay particular attention to conflicting goals and tensions, to help address these in more transparent and equitable ways, and to foster a thinking in terms of co-benefits. 
TABLE 6 | Comparison of assessment criteria with the food chain governance improvements proposed.

\begin{tabular}{|c|c|c|}
\hline Chain governance dimensions & Specific indicators & Improvements proposed \\
\hline Enabling environment and institutions & $\begin{array}{l}\text { 1. Socio-cultural factors (informal). } \\
\text { 2. Laws and regulations. } \\
\text { 3. Non-market mechanism (e.g., quality standards and } \\
\text { initiatives). } \\
\text { 4. Investment and finance service (e.g., microfinance) }\end{array}$ & $\begin{array}{l}\text { Acknowledging role of the informal food sector through government } \\
\text { institutions by Lusaka (Indicator 2). } \\
\text { Development of infrastructures and extension services by Bahir Dar } \\
\text { (Indicator 4). } \\
\text { Improving the availability of credit by Bahir Dar and Chongwe (Indicator } \\
\text { 4). } \\
\text { Provision of financial opportunities such as microfinance by Cotonou } \\
\text { (Indicator 4). } \\
\text { The rules and regulations of fishing by Bahir Dar (Indicator 2). } \\
\text { Developing a buffer zone of lakes by Bahir Dar (Indicators } 2 \text { and 4). }\end{array}$ \\
\hline Governance structures & $\begin{array}{l}\text { 5. Spot/cash markets. } \\
\text { 6. Contract governance (market contracts and } \\
\text { production contracts, contract farming). } \\
\text { 7. Relation governance (relation-based alliances; } \\
\text { equity-based alliances; and vertical integration). }\end{array}$ & $\begin{array}{l}\text { Not reflected by regional food system actors. This needs to be } \\
\text { checked in further discussions. }\end{array}$ \\
\hline $\begin{array}{l}\text { Governance structure dynamics and } \\
\text { determinants }\end{array}$ & $\begin{array}{l}\text { 8. Access to information and knowledge. } \\
\text { 9. Participation in partnership networks. } \\
\text { 10. Competences of farmers and SMEs. } \\
\text { 11. Price determination. } \\
\text { 12. Value-added. }\end{array}$ & $\begin{array}{l}\text { Facilitate marketing at better prices by direct linkages between farmers } \\
\text { and buyers by Rwamwanja (Indicator } 8 \text { ). } \\
\text { Improve maize packaging and labeling by Rwamwanja (Indicator 12). } \\
\text { Establish a processing center by Rwamwanja and Bahir Dar (Indicator } \\
\text { 12). } \\
\text { Put in place chicken feed production facilities by Rwamwanja (Indicator } \\
\text { 10). } \\
\text { Ensuring access to seeds and other inputs and training by Chongwe } \\
\text { and Cotonou (Indicators } 8,9,10 \text { ). } \\
\text { Facilitation of bulking through the functioning of cooperatives to access } \\
\text { larger markets by Chongwe and Kisumu (Indicators } 9,10,11,12 \text { ). } \\
\text { Promoting simple food preservation technologies to enable long shelf } \\
\text { life by Lusaka and vegetable conservation by Cotonou (Indicators 11, } \\
\text { 12). } \\
\text { Increasing the availability of market information by Lusaka (Indicator } 8 \text { ). } \\
\text { Cool chain for reduction of post-harvest losses by Chongwe, Kisumu, } \\
\text { Bahir Dar (Indicators } 11,12 \text { ). }\end{array}$ \\
\hline $\begin{array}{l}\text { Governance structure and relationship } \\
\text { strength }\end{array}$ & $\begin{array}{l}\text { 13. Linkages between chain actors. } \\
\text { 14. Cooperatives and associations. } \\
\text { 15. Multi-stakeholder platform. }\end{array}$ & $\begin{array}{l}\text { Farmer groups to produce maize by Rwamwanja (indicator 14). } \\
\text { Strengthening relationship between farmer cooperatives, trader } \\
\text { associations, city council and Ministry of Commerce Trade and Industry } \\
\text { by Chongwe (indicators } 13 \text { and 14). } \\
\text { Farmer cooperatives by Kisumu and farmer's marketing cooperatives } \\
\text { by Bahir Dar (indicator 14). } \\
\text { Introducing contract farming by Bahir Dar (indicator 13). }\end{array}$ \\
\hline
\end{tabular}

Overall, we can conclude that the assessment framework can help to improve the efficiency and functioning of food chains. It can inform agri-food chain actors as well as policy development concerning an efficient functioning of agri-food chains. Our first testing of the approach sheds light on the strengths of an indicators-based assessment. The indicator set pays particular attention to food chains and governance arrangements aimed at providing healthy and nutritious and sustainable food for local consumers, and to empowering small and medium-sized farms, processors and retailers.

We think that the indicator set may well be applicable in other contexts and food chains where the focus is on fostering healthy diets among local consumers and sustainable food production, as well as the empowerment of food chain actors. However, further testing and refinement are required to make the assessment framework more widely applicable. This can very well be done together with key food chain actors in the six study regions in conjunction with the planned piloting and monitoring of food system changes, and thus in the spirit of co-learning and codevelopment.

\section{DATA AVAILABILITY STATEMENT}

The original contributions presented in the study are included in the article/supplementary material, further inquiries can be directed to the corresponding author/s.

\section{AUTHOR CONTRIBUTIONS}

QC is responsible for completing the first draft of the manuscript and for revising the manuscript based on all co-authors' comments. KK has greatly contributed to the whole structure and the logic of the manuscript. MT and JS have mainly commented 
on the indicator framework. All co-authors have read, revised, and approved the final manuscript.

\section{FUNDING}

This study was financially supported by the European Union's Horizon 2020 project HealthyFoodAfrica (HFA) under grant agreement No. 862740. The collaboration with the six urban and peri-urban regions in Sub-Saharan Africa (in Benin, Ethiopia, Kenya, Uganda, and Zambia), the called six localized,

\section{REFERENCES}

Abel, B., Gor, C. B., Okuro, S. O., Omanga, P. A., and Bokelmann, W. (2019). The African indigenous vegetables value chain governance in Kenya. Stud. Agric. Econ. 121, 41-52. doi: 10.7896/j.1818

Achterbosch, T., van Drop, M., van Driel, W. F., Groot, J. J., van der Lee, J., and Bezlepkina, I. (2014). The Food Puzzle: Pathways to Securing Food for All. The Research Programme Global Food Security: Scarcity and Transition by Wageningen UR. Wageningen: Wageningen UR.

Amentae, T. K., Gebresenbet, G., and Ljungberg, D. (2018). Examining the interface between supply chain governance structure choice and supply chain performances of dairy chains in Ethiopia. Int. Food Agribusiness Manag. Rev. 21:2018. doi: 10.22434/IFAMR2018.0001

Arato, M., Speelman, S., Dessein, J., and van Huylenbroeck, G. (2017). Assessment of socio-economic configuration of value chains: a proposed analysis framework to facilitate integration of small rural producers with global agribusiness. Int. Food Agribusiness Manag. Rev. 20:2017. doi: 10.22434/IFAMR2015.0060

Ayele, S., Duncan, A., Larbi, A., and Khanh, T. T. (2012). Enhancing innovation in livestock value chains through networks: Lessons from fodder innovation case studies in developing countries. Sci. Public Policy. 39, 333-346. doi: $10.1093 / \mathrm{scipol} / \mathrm{scs} 022$

Berti, G., and Mulligan, C. (2016). Competitiveness of small farms and innovative food supply chains: the role of food hubs in creating sustainable regional and local food systems. Sustainability. 8:616. doi: 10.3390/su8070616

Bui, S., Costa, I., De Schutte, O., Dedeurwaerdere, T., Hudon, M., and Feyereisen, M. (2019). Systemic ethics and inclusive governance: two key prerequisites for sustainability transitions of agri-food systems. Agric. Hum. Values. 36, 277-288. doi: 10.1007/s10460-019-09917-2

Carletto, G., Ruel, M., and Winters, P. (2015). Farm-level pathways to improved nutritional status: introduction to the special issue. J. Dev. Stud. 51, 945-957. doi: 10.1080/00220388.2015.1018908

Cernansky, R. (2015). The rise of Africa's super vegetables. Nature 522, 146-148. doi: $10.1038 / 522146 a$

Demsetz, H. (1988). The theory of the firm revisited. J. Law Econ. Organ. $4,141-161$.

FAO (2014). Developing Sustainable Food Value Chains - Guiding Principles. Rome: FAO.

Gachukia, M. W. (2015). Moderating effect of traceability on value chain governance of credence goods: a perspective of the New Institutional Economics framework. Stud. Agric. Econ. 117, 102-110. doi: 10.7896/j.1513

Gereffi, G., Humphrey, J., and Sturgeon, T. (2005). The governance of global value chains. Rev. Int. Polit. Econ. 12, 78-104. doi: 10.1080/09692290500049805

Guéneau, S. (2018). Neoliberalism and the emergence of private sustainability initiatives: the case of the brazilian cattle value chain. business strategy and the environment bus. Strat. Environ. 27, 240-251. doi: 10.1002/bse.2013

Hattersley, L. (2013). Agri-food system transformations and diet-related chronic disease in Australia: a nutrition-oriented value chain approach. Agric. Hum. Values 30, 299-309. doi: 10.1007/s10460-012-9411-9

Helmsing, A. H. J., and Vellema, S. (2011). Value Chains, Inclusion and Endogenous Development Contrasting Theories and Realities. Abingdon, VA: Routledge. doi: $10.4324 / 9780203816806$ context-specific Food System Labs (FSLs) in the HFA project, are highly appreciated. These six FSLs are (1) FSL-Rw | Rwamwanja refugee settlement, S.W. Uganda, led by Finn Church Aid (FCA). (2) FSL-Ch | Chongwe District, Lusaka Province, S.E. Zambia, led by Hivos. (3) FSL-Lu | Lusaka, Lusaka Province, S.E. Zambia, led by Hivos. (4) FSL-Ki | Kisumu, Kisumu County, W. Kenya, led by Bioversity. (5) FSL-BD | Bahir Dar city and Koga irrigation area, Amhara Regional State, N. Ethiopia, led by Bahir Dar University (BDU). (6) FSL-Co | Cotonou, Littoral Department, S. Benin, led by University of Abomey-Calavi (UAC).

HLPE (2017). Nutrition and Food Systems. A Report by the High-Level Panel of Experts on Food Security and Nutrition of the Committee on World Food Security. Rome: HLPE.

Holmes, M. D., Dalal, S., Sewram, V., Diamond, M. B., Adebamowo, S. N., Ajayi, I. O., et al. (2018). Consumption of processed food dietary patterns in four African populations. Public Health Nutr. 21, 1529-1537. doi: $10.1017 /$ S136898001700386X

Imamura, F., Micha, R., Khatibzadeh, S., Fahimi, S., Shi, P. L., Powles, J., et al. (2015). Dietary quality among men and women in 187 countries in 1990 and 2010: a systematic assessment. Lancet Glob. Health. 3, 132-142. doi: 10.1016/S2214-109X(14)70381-X

Ingram, V., van den Berg, J., van Oorschot, M., Arets, E., and Judge, L. (2018). Governance options to enhance ecosystem services in cocoa, soy, tropical timber and palm oil value chains. Environ. Manag. 62, 128-142. doi: 10.1007/s00267-018-0996-7

Jordaan, H., Grové, B., and Backeberg, G. R. (2014). Conceptual framework for value chain analysis for poverty alleviation among smallholder farmers. Agric. Econ. Res. Policy Pract. Southern Afr. 53, 1-25. doi: 10.1080/03031853.2014.887903

Kilelu, C., Klerkx, L., Omore, A., Baltenweck, I., Leeuwis, C., and Githinji, J. (2017). Value chain upgrading and the inclusion of smallholders in markets: reflections on contributions of multi-stakeholder processes in dairy development in Tanzania. Eur. J. Dev. Res.29, 1102-1121. doi: 10.1057/s41287-016-0074-z

Kline, C. S., Joyner, L. E., Kirchoff, J. F., Crawford, A., Pitts, S. J., Wall-Bassett, E., et al. (2016). Gaps and barriers along the North Carolina agri-food value chain. Br. Food J. 118, 301-317. doi: 10.1108/BFJ-06-2015-0223

Knickel, K., Zerger, C., Jahn, G., and Renting, H. (2008). Limiting and enabling factors of collective farmers' marketing initiatives: results of a comparative analysis of the situation and trends in 10 European countries. J. Hunger Environ. Nutr. 3:2008. doi: 10.1080/19320240802244041

Leat, P., and Revoredo-Giha, C. (2013). Risk and resilience in agri-food supply chains: the case of the ASDA Pork Link supply chain in Scotland. Supply Chain Manag. 18, 219-231. doi: 10.1108/13598541311318845

Maestre, M., Poole, N., and Henson, S. (2017). (2017). Assessing food value chain pathways, linkages and impacts for better nutrition of vulnerable groups. Food Policy 68, 31-39. doi: 10.1016/j.foodpol.2016.12.007

Milagrosa, A. (2007). Institutional economic analysis of vegetable production and marketing in northern philippines: social capital, institutions and governance (Ph.D. Thesis). Wageningen University, Wageningen, Netherlands

Murshed, E. J., and Pemsl, D. E. (2011). The impact of integrated aquaculture agriculture on small scale farm sustainability and farmers' livelihoods: experience from Bangladesh. Agric. Syst. 104, 392-402. doi: 10.1016/j.agsy.2011.01.003

Olney, D. K., Pedehombga, A., Ruel, M. T., and Dillon, A. (2015). A 2-year integrated agriculture and nutrition and health behavior change communication program targeted to women in burkina faso reduces anemia, wasting, and diarrhea in children 3-12, 9. months of age at baseline: a cluster-randomized controlled trial. J. Nutr. 145, 1317-1324. doi: $10.3945 /$ jn. 114.203539

Oro, K., and Pritchard, B. (2011). The evolution of global value chains: displacement of captive upstream investment in the Australia-Japan beef trade. J. Econ. Geogr. 11, 709-729. doi: 10.1093/jeg/lbq008 
Ouma, E., Ochieng, J., Dione, M., and Pezo, D. (2017). Governance structures in smallholder pig value chains in Uganda: constraints and opportunities for upgrading. Int. Food Agribusiness Manag. Rev. 20:2017. doi: 10.22434/IFAMR2014.0176

Peterson, H. C., Wysocki, A., and Harsh, S. B. (2001). Strategic choice along the vertical coordination continuum. Int. Food Agribusiness Manag. Rev. 4, 149-166. doi: 10.1016/S1096-7508(01)00079-9

Renting, H., and Marsden, T. (2003). Understanding alternative food networks: exploring the role of short food supply chains in rural development. Environ. Plann. A 35, 393-411. doi: 10.1068/a3510

Ros-Tonen, M., Van Leynseele, V. B., Laven, A., and Sunderland, T. (2015). Landscapes of social inclusion: inclusive value-chain collaboration through the lenses of food sovereignty and landscape governance. Eur. J. Dev. Res. 27, 523-540. doi: 10.1057/ejdr.2015.50

Stone, J., and Rahimifard, S. (2018). Resilience in agri-food supply chains: a critical analysis of the literature and synthesis of a novel framework. Supply Chain Manag. 23, 207-238. doi: 10.1108/SCM-06-20 17-0201

Sureau, S., Lohest, F., Van Mol, J., Bauler, T., and Achten, W. M. J. (2019). How do chain governance and fair trade matter? An S-LCA methodological proposal applied to food products from belgian alternative chains (Part 2). Resources 8:145. doi: 10.3390/resources8030145

Tallontire, A., Opondo, M., Nelson, V., and Martin, A. (2011). Beyond the vertical? Using value chains and governance as a framework to analyse private standards initiatives in agri-food chains. Agric. Hum. Values 28, 427-441. doi: 10.1007/s10460-009-9237-2

Trienekens, J. H. (2011). Agricultural value chains in developing countries a framework for analysis. Int. Food Agribusiness Manag. Rev. 14, 51-82. doi: 10.22004/ag.econ.103987
Van der Ploeg, J. D., and Marsden, T. K. (2008). Unfolding Webs: The Dynamics of Regional Rural Development. Assen: Van Gorcum.

Vlachos, I. P. (2014). The impact of private label foods on supply chain governance. Br. Food J. 116, 1106-1127. doi: 10.1108/BFJ-09-2012-0228

Yang, H., Vernooy, R., and Leeuwis, C. (2018). Farmer cooperatives and the changing agri-food system in China. China Inform. 32, 423-442. doi: $10.1177 / 0920203 X 16684504$

Zhang, X. Y., and Aramyan, L. H. (2009). A conceptual framework for supply chain governance: An application to agri-food chains in China. China Agric. Econ. Rev. 1, 136-154. doi: 10.1108/17561370910927408

Conflict of Interest: The authors declare that the research was conducted in the absence of any commercial or financial relationships that could be construed as a potential conflict of interest.

Publisher's Note: All claims expressed in this article are solely those of the authors and do not necessarily represent those of their affiliated organizations, or those of the publisher, the editors and the reviewers. Any product that may be evaluated in this article, or claim that may be made by its manufacturer, is not guaranteed or endorsed by the publisher.

Copyright (C) 2021 Chen, Knickel, Tesfai, Sumelius, Turinawe, Isoto and Medyna. This is an open-access article distributed under the terms of the Creative Commons Attribution License (CC BY). The use, distribution or reproduction in other forums is permitted, provided the original author(s) and the copyright owner(s) are credited and that the original publication in this journal is cited, in accordance with accepted academic practice. No use, distribution or reproduction is permitted which does not comply with these terms. 